\title{
KEYNES, MILL, AND SAY'S LAW: THE LEGITIMATE CASE KEYNES DIDN'T MAKE AGAINST J. S. MILL
}

BY

ROY H. GRIEVE

\begin{abstract}
Having in the General Theory quoted a passage from John Stuart Mill's Principles as representative of ancient confusion, John Maynard Keynes has been accused of misinterpreting that passage and thus mistakenly identifying Mill as an upholder of the "classical" proposition that "supply creates its own demand." Certain critics, seizing on Keynes's misunderstanding, draw the conclusion that little was actually wrong with Mill's analysis and that Keynes's attack on Mill was therefore without justification.

Our contention, however, is that, despite his error with respect, so to say, to the "letter" of Mill's exposition, Keynes was right about the essential "substance" of Mill's thesis. Mill's thinking, we suggest, was deeply in thrall to the ideas of his father and Jean-Baptiste Say. The purpose of this paper is to demonstrate that Mill did indeed stand for a "classical" position, albeit qualified, but nevertheless vulnerable to Keynes's critique as developed in the General Theory.
\end{abstract}

\section{INTRODUCTION}

In setting out in the General Theory his critique of the "classical" position, John Maynard Keynes (1936, p. 18) accused John Stuart Mill of holding to the doctrine that "supply creates its own demand," citing as evidence a passage from Mill's (1866) Principles of Political Economy. Several critics—for instance, Don Patinkin (1965), ${ }^{1}$

Roy H. Grieve, Formerly University of Strathclyde roygrieve@btinternet.com. I am grateful to Eric Rahim, Geoff Harcourt, Steve Meardon, and anonymous referees for valued comment on earlier drafts of this paper. Remaining deficiencies are of course my responsibility.

${ }^{1}$ Referring to the passage quoted by Keynes, Patinkin (1965, p. 647) comments that "this passage expresses nothing more objectionable than the innocuous 'national income equals national product' identity of contemporary social accounting." Patinkin, that is to say, was pointing out that, even from a Keynesian perspective, there was in fact nothing wrong with what Mill was saying in the passage Keynes chose to highlight! 
Axel Leijonhufvud (1966), ${ }^{2}$ and Robert A. Mundell (1968) ${ }^{3}$ - have risen to the defence of Mill, pointing out that he evidently did not mean by the passage in question what Keynes took him to mean - the implication being that as, clearly, there was nothing in the highlighted passage to which, from a Keynesian perspective, exception could legitimately be taken, Keynes's attack on Mill was unjustified.

The purpose of this paper, however, is to establish the validity of Keynes's charge that Mill's treatment of the question of the adequacy of intended total expenditure to ensure full use of the community's productive resources was indeed seriously flawed. We argue that while Keynes did misinterpret the quoted passage, he was nevertheless correct in identifying Mill as an upholder of the "classical" thesis that it is production that determines demand, and not vice versa. Mill, as he himself declared, did consistently adhere to the essential doctrine of his father and Jean-Baptiste Say, though offering a nuanced version to accommodate the undeniable real-world situation of a simultaneous general excess demand for money and excess supply of goods. Mill, it would appear, was trying to keep his Sayian cake as well as eating it. The defenders of Mill against Keynes have evidently failed to appreciate just how problematic Mill's analysis, taken as a whole, actually is when viewed from a Keynesian perspective. ${ }^{4}$

\footnotetext{
${ }^{2}$ Leijonhufvud (1966, p. 161n29) also makes the point that Keynes's reading of Mill was incorrect: "having selected his quote from J. S. Mill's Principles, Keynes did not bother to finish reading the paragraph . . . much less the rest of that very brief chapter [in which Mill stated] 'At such times there is really an excess of all commodities above the money demand: in other words there is an under-supply of money ... so that there may be an extreme depression of general prices, from what may be indiscriminately called a glut of commodities or a dearth of money.' . . . surely, had he seen these statements, Keynes could not have attributed Say's Law in the sense of Lange to Mill.” Thus, like Patinkin, Leijonhufvud observes that Keynes was finding fault with Mill where none existed.

${ }^{3}$ Mundell (1968, p. 110) goes so far as to argue that Keynes, not finding anything particularly damning in Mill, may have deliberately misrepresented Mill's meaning in order to create a "classical" straw man for public demolition. The following is Mundell's take on the matter:

\begin{abstract}
"Keynes, attacking Mill's proposition, which he had quoted, left out the last half of the [quoted] paragraph . . . in which Mill made his meaning explicit. Whether this omission was by design or carelessness is not clear. What is evident, however, is that Keynes perpetrated a historical error in the economics profession lasting several years, a distortion of the classical position that to this day remains in the elementary textbooks. By thus attacking the logic of a central feature of the classical theory through carelessness or mischievous omission of its central parts, Keynes was able to win disciples over to the belief that there was a fatal logical defect, an absurd premise, in the classical system. The classicists were guilty, according to Keynes, of believing in Say's Law."
\end{abstract}

\footnotetext{
4"Viewed from a Keynesian perspective": even if it is from a Keynesian standpoint that we approach the question of whether (as alleged by some commentators) Mill's theory is compatible with that of Keynes, we need to be aware of differences in the respective conceptual frameworks. Steven Kates (2015) makes the point that a "discontinuity" exists between the modern way of conceiving the meaning of economic issues and how they were understood by the classics. For instance, "saving" can be interpreted in classical terms as "spending" (on productive labor). He adds: "the basis for understanding Mill is dependent on a proper understanding of Say's Law as it was understood by Mill and his classical contemporaries, . . . an understanding . . . almost entirely lost with the publication of John Maynard Keynes's General Theory ... ." We agree that to make sense of Mill we need to appreciate how, in terms of his own conceptual framework-a framework fundamentally shaped by the ideas of his father and J. B. Say-Mill arrived at his conclusions. Although he did not blindly accept the received doctrine, he nevertheless continued to think in terms of a theoretical framework derived from their (Say's Law) doctrine. We do not, however, believe, even taking account of Kates's "discontinuity," that Mill's conception need be incomprehensible to a modern reader.
} 


\section{THE MISQUOTATION IN QUESTION}

In attacking what he saw as the fundamental deficiency of the classical theory of employment, Keynes argued (1936, p. 18) that:

From the time of Say and Ricardo the classical economists have taught that supply creates its own demand:-meaning by this in some significant, but not clearly defined, sense that the whole of the costs of production must necessarily be spent in the aggregate, directly or indirectly, in purchasing the product.

The quotation from Mill immediately follows in illustration:

In J. S. Mill's Principles of Political Economy the doctrine is explicitly set forth: "What constitutes the means of payment for commodities is simply commodities. Each person's means of paying for the productions of other people consist of those which he himself possesses. All sellers are inevitably, and by the meaning of the word, buyers. Could we suddenly double the productive powers of the country, we should double the supply of commodities in every market, but we should, by the same stroke, double the purchasing power."

The critics charge Keynes with misquotation on the ground that Mill did not intend the passage to carry the meaning Keynes evidently attributes to it, as indicating Mill's acceptance of what has been termed "Say's Identity": the proposition that all sales receipts are automatically and immediately spent on purchasing goods and services. Indeed, it can readily be demonstrated - as the critics have done by setting the passage in context - that that was not the point Mill was making.

The passage in question derives from the Principles (bk. III, ch. xiv), in which Mill is developing his argument against what he considered the "heretical" view (attributed to "Malthus, Chalmers and Sismondi") 5 that "a general oversupply of all commodities in relation to overall demand is an occurrence to be feared." In tackling the issue Mill proposes that "the two elements of demand"- "the desire to possess" and "the means of purchase"- each be examined.

Concentrating first on "the means of purchase," he invites readers to assume that "the quantity of all commodities produced is not greater than the community would be glad to consume." The question, therefore, is whether, if the community does collectively wish to buy all the commodities it produces, could it possibly be prevented from doing so by lack of purchasing power? Mill's answer is no, that cannot happen: the reason being that, when commodities are exchanged on the market, the goods each transactor offers for sale are simultaneously elements of supply and potential instruments of demand. If, as assumed, every transactor is able to sell all that he wishes, the value of each individual's effective purchasing power is equal to the value of what he sells on the market; consequently, the value of the total available purchasing power is necessarily equal to the value of total supply. Ergo, when members of the community wish to buy all that is on offer, sales cannot be constrained for want of adequate purchasing power.

\footnotetext{
${ }^{5}$ Mill identifies the trio of T. R. Malthus, Thomas Chalmers, and J. C. L. S. de Sismondi as the principal exponents of the "heretical" doctrine that the adequacy of overall intended expenditure to ensure full absorption of output offered for sale cannot be taken for granted.
} 
Thus, as Patinkin (1965, p. 47) observes, the passage "cannot refer to the willingness to consume - as Keynes would have it—but to the power to consume."

There is no question that Mill actually did recognize that agents might, on occasion, prefer to retain money in hand rather than part with it in exchange for commodities. Thus in his essay Of the Influence of Consumption on Production (1844, p. 276) Mill clearly accepted that income receipts may be reserved unspent, retained in hand until "a year hence, or whenever it shall be most convenient." Consequently,

[b]uying and selling ... [thus] being separated, it may well occur that there may be, at some given time, a very general inclination to sell with as little delay as possible, accompanied by an equally general inclination to defer all purchases as long as possible. This is always actually the case, in those periods which are described as periods of general excess.

Recognizing that Mill did accept the possibility of money being withheld from expenditure, a considerable body of modern opinion concludes that his macroeconomic thinking could not, therefore, have been significantly at odds with the Keynes theory. Thus several writers have given Mill's macroeconomics (from a Keynesian perspective) a pretty clean bill of health. Gary S. Becker and William J. Baumol (1952, p. 374), referring to Mill's account of a commercial crisis, observed:

[It] is all there and explicitly-Walras' Law, Say's Identity which Mill points out holds only for a barter economy, the "utility of money" which consists in permitting purchases to be made when convenient, the possibility of (temporary) oversupply of commodities when money is in excess demand, and Say's Equality which makes this only a temporary possibility.

Samuel Hollander (1979, p. 75) endorses the Becker and Baumol appraisal. Recognizing Mill's admission of the possible occurrence of excess supplies of labor and commodities along with an excess demand for money, Hollander is of the opinion that it is merely Mill's "presumption against a 'Keynes-like unemployment equilibrium" that chiefly separates him from a Keynesian position.

Thomas Sowell (1994, pp. 48-49) comments that Mill, having disposed of the "dissidents," discusses "the real substance of the issue more clearly and thoroughly than any other classical economist." He points to Mill's acknowledgment, in both his 1844 Essay and in the Principles, that, on the occasion of a commercial crisis, there "is really an excess of all commodities" and "an undersupply of money."

In an early reaction to Keynes's comment on Mill, Frank Knight (1937) expressed the opinion that if account is taken of Mill's recognition of an emergent demand for money in times of particular uncertainty, nothing is left of Keynes's case against Mill.

Mundell's response (1968, p. 110) to the misquotation is particularly hostile to Keynes: he airs a suspicion of deliberate misrepresentation —of Keynes mischievously distorting the classical argument to create a straw-man target. The result, says Mundell, is to create a false impression that classical treatment of the determination of aggregate demand was fundamentally flawed.

However J. Ronnie Davis and Frank C. Casey (1977), on the basis of an ingenious piece of literary detective work, reject Mundell's distasteful suggestion that Keynes knowingly misrepresented Mill: they demonstrate convincingly that although Keynes was in error in his use of the quotation, he was guilty of nothing worse than carelessness 
in failing to check its original source in Mill's work. Finding the passage in a secondary source where it had been misleadingly "torn out of context" (Patinkin's phrase, 1965, p. 647), he misread its meaning. Davis and Casey suggest that Keynes presented the quotation in good faith, misrepresentation occurring through genuine misunderstanding. 6

Where, we must ask, do the above opinions leave us on the question of the propriety of Keynes's charge against Mill? If Mill, contrary to Keynes's allegation in the General Theory, did not hold by a crude Identity version of Say's Law, was Keynes's attack on Mill as representing an untenable "classical" orthodoxy simply without foundation? We believe-as we shall try to explain in this paper-that there is more to this matter than Keynes's critics have recognized. Granted that Mill did allow the possibility of agents' holding on to money in times of crisis, we nevertheless take the view that Mill's general conception was fundamentally different from that of Keynes; Mill supposed that demand naturally corresponded to the value of output, unless spending intentions were frustrated by abnormal monetary conditions. ${ }^{7}$ For Mill, following the view of his father and of Say, the volume of intended demand for output is not, of itself, something to worry about as a possible cause of unemployment.

While we agree that, in the passage quoted, Mill was saying nothing to which Keynes could legitimately object, it must be remembered, however, that the passage relates to only one part of Mill's argument (the part concerning the "means of purchase"); it does not follow that the rest of his discussion relating to the "desire to possess" is equally unexceptionable. Curiously enough, the critics who have so eagerly pointed to Keynes's misunderstanding appear to have neglected the subsequent part of Mill's argument. We could say that in exonerating Mill of Keynes's charge of holding by Say's Identity, the critics have somehow managed to overlook a very large "elephant in the room"- -an elephant in the form of Mill's explanation of the determination of aggregate expenditure in normal (non-crisis) circumstances. Had they given this fundamental component of Mill's analysis due attention, they could not, we believe, have presumed Mill to be in the clear on the "general glut" issue: it is with Mill's handling of the desire to possess- the will to buy - that, from the Keynesian perspective, a problem arises.

In fact, it can be said that while Keynes singled out Ricardo in particular as being responsible for establishing the "classical" tradition of denying the possibility of

\footnotetext{
${ }^{6}$ Davis and Casey, noting disparities of detail between Mill's original text and similarly inaccurate versions reproduced by Marshall and Marshall (1879), Mummery and Hobson ([1889] 1956), and Keynes (1936), suggest that Keynes derived the Mill passage at second or third hand from the Marshalls or from Mummery and Hobson and not directly from Mill's Principles. Observing that Keynes had been reading (with warm approval) Mummery and Hobson just prior to amending a draft of Chapter 2 to include the Mill passage (see Keynes 1973, pp. 653, 537), and that Richard Kahn subsequently sent Keynes a copy of the Marshalls' text, we reckon that Keynes's source of the passage in question, initially excerpted out of context by the Marshalls, and later borrowed from them by Mummery and Hobson, was in fact the Mummery and Hobson volume. It would thus appear that Keynes's misunderstanding of the passage he inserted in the General Theory was attributable to the Marshalls' mutilation of Mill's more complete discussion, and the repetition of the Marshallian version by Mummery and Hobson. It may be added that J. K. Whitaker (1975, p. 215n) refers to Marshall's (apparently habitual) "loose style of quotation."

${ }^{7}$ Unemployment could occur also if, with a changing pattern of demand, expenditure is constrained by slow adaptation of production to the new conditions (a Ricardo theme). Also, in the latter neoclassical era, it was allowed that potential demand may be ineffective if employment is limited by excessive real wages (the Pigou 1933 thesis). The conventional opinion was that, without such complications, demand could be relied upon to take up whatever output corresponded to full employment.
} 
deficient demand's causing unemployment, Mill must carry a large part of the blame: Mill presented a much more elaborate defence of the proposition, and his Principles, being used for so long as the authoritative text on political economy, must have had a very powerful influence in creating the conventional wisdom.

To show that a problem does exist, we need to place Mill's analysis under the microscope and examine his views regarding the sufficiency-or otherwise-of total spending to absorb all output produced. It is convenient to take Mill's treatment of demand and employment in two parts: one concerned with the circumstances of a commercial crisis, and a second dealing with the question of the adequacy of effective demand to support full employment under normal (non-crisis) conditions.

\section{MILL ON COMMERCIAL CRISES: A CRISIS IS NOT A “GLUT” AS ENVISAGED BY THE HERETICS}

Mill, unlike his father, ${ }^{8}$ was fully prepared to admit that a commercial crisis could (at least temporarily) give rise to an excess supply of goods, even generally across the economy; at the same time he argued that the resulting unemployment provided no justification for the "heretical" fear that such a situation could originate autonomously from want of desire to acquire the products of industry. In other words Mill's contention was that, despite the observed occurrence from time to time of widespread unemployment, Thomas Robert Malthus, Thomas Chalmers, and Jean Charles Leonard Simonde de Sismondi were completely wrong in their diagnosis that such conditions were the result of an overall imbalance between the community's demand for goods and services and the economy's ability to produce those goods and services.

We begin with Mill's argument that the "heretics" had misunderstood the true nature of a "commercial crisis." He emphasizes that, as he understands it, a commercial crisis is something very different from, and not to be confused with, a slowly developing "general glut." Mill (1866, bk. III, ch. xiv, p. 4) defined a commercial crisis as a sudden and sharp, but merely temporary, self-correcting interruption of normal commercial activity. Such a disturbance he interpreted as resulting not from insufficient intended demand, but from the opposite state of affairs: from a speculative excess of demand, resulting in market collapse, bankruptcies, a credit crunch, and forced postponement of expenditure. In the ensuing panic and general fear of insolvency, traders are desperate to get their hands on ready money, but that proves no easy matter. Everyone is disposed "not only to refuse fresh credit, except on very onerous terms, but to call in, if possible, all credit . . . already given; . . . bankers raise their rate of discount, and withhold their customary advances; merchants refuse to renew mercantile bills." And therefore: "There may easily be, though only while the crisis lasts, an extreme depression of general prices, from what may indiscriminately be called a glut of commodities or a dearth of money" (emphasis added).

\footnotetext{
${ }^{8}$ Samuel Hollander (1985, pp. 489-508) describes how Mill, having initially followed his father in denying the occurrence of general overproduction, later allowed that, at least in a "commercial crisis," total spending could undeniably be deficient in relation to output and production capacity.
} 
Thus Mill does admit the possibility of a general excess supply of commodities along with a simultaneous excess demand for money, but at the same time strongly denies that such circumstances correspond to those of a "glut" as predicted by Malthus et al. Mill holds that a crisis situation can be explained without citing overproduction relative to the wants of the community. As Mill sees the situation, in a crisis agents are hanging on to their money rather than spending it-not because their needs are sated with a superabundance of goods but because, in the prevailing (but short-lived) circumstances of a crisis, it could quite probably mean commercial suicide to do otherwise.

Mill attributes withholding of spending under crisis conditions to extreme anxiety in the markets, resulting from the bursting of a speculative bubble and the consequent breakdown of normal commercial trust in the mechanisms of purchase and sale, of lending and borrowing. Intended expenditures are postponed-not cancelled. Correspondingly Mill believes that "restoration of confidence"9_-dissolution of the prevailing "general distrust"-is all that is required for recovery. Once the "temporary derangement of markets" has passed, agents, freed from fear of abnormal commercial risks, can, he believes, be expected to resume their interrupted activities. When the blizzard of bankruptcies has blown over, business will quickly return to normal. "It is true that this state [of excess demand for money] can only be temporary, and must even be succeeded by a reaction of corresponding violence, since those who have sold will certainly buy at last, and there will then be more buyers than sellers" (Mill 1866, bk. III, ch. xiv, p. 3).

Evidently Mill did not recognize the possibility that, even after the chaotic conditions of a commercial crisis have passed and a calmer state of affairs has returned, investors' assessments of longer term prospects could have become less favorable than previously. Thus, as Hollander notes (1979, p. 475; 1985, p. 503), Mill's belief in automatic recovery-even in a dramatic rebound-precludes recognition of the likelihood of persisting unemployment (unemployment equilibrium) of a Keynesian character. That is so because, as we have seen, Mill's focus is on a different causative factor from that identified by Keynes. For Mill, when a financial crisis occurs, what is crucial is agents' loss of confidence in the solvency of those with whom they normally do business, resulting in the disruption of normal commercial activity. This is in the nature of a mechanical-but, as Mill sees it, temporary and self-correctingbreakdown of the system of trade and finance. Compare Keynes's quite different view (1936, p. 316), that in recession it is the "collapse of the marginal efficiency of capital which renders the slump so intractable." By contrast, as envisaged by Mill, recovery poses no problem: the adequacy of demand for output under normal, noncrisis conditions is not a matter for concern. No concern? As will be explained in the following section of this paper, Mill held that the very act of production implies, under normal conditions, the existence of a corresponding demand for output; in other words, if the commercial mechanisms of trade and finance are working properly, the value of intended expenditure must match the value of income generated through production.

\footnotetext{
${ }^{9} \mathrm{By}$ "restoration of confidence" Mill means re-establishment of a normal degree of trust in the solvency of those with whom business is conducted; Mill is not referring (à la Keynes) to confidence regarding the existence of adequate demand for output under non-crisis conditions (with Mill, that could be taken for granted).
} 
To sum up on Mill's interpretation of a commercial crisis: during a commercial upheaval, intended expenditures are put on hold and cash retained in hand, but when normality returns (as it soon will) and everyone's solvency is no longer in question, spending plans that had been shelved under crisis conditions are brought back into play; intended but postponed expenditures become actual demand. Mill's account of a crisis (while realistic, up to a point) does not comprehend the Keynesian understanding that the problem is not simply that the "desire to possess" is temporarily frustrated by monetary disruption and institutional breakdown, but that, even without such disruption, or when the disruption has passed, that desire may actually be deficient.

It is revealing that Patinkin (1965, pp. 649-650n25) complains that Mill offers no explanation as to how-whether via falling interest rates or the real balance effect-demand is supposed to be stimulated and activity restored following a crisis. But from Mill's perspective there is no such problem in achieving recovery-to him, Patinkin's concern would have been beside the point. Mill would have seen no need of such stimuli to boost demand-intended demand has not collapsed; it is merely a matter of allowing a little time for the paralyzing fear of widespread insolvency to subside.

While Mill thus accepts that, from time to time, there may be observed a general flight to money and excess supply of goods, he will not countenance the idea that such a state of affairs is indicative of an overall deficiency of intended spending relative to productive capacity, as predicted by the "general glut" theorists. But he does not simply deny that the heretics' claim is supported by real-world experience: the principal element (to which we now come) of Mill's case against dissenting opinion is an attempted demonstration that it is actually impossible for a general problem to occur with "the desire to possess."

\section{MILL'S BASIC ARGUMENT}

We turn now to the second element of Mill's analysis: his positive case against Malthus and the other heretics. Recall that (as mentioned above) a number of scholars-Knight (1937), Becker and Baumol (1952), Mundell (1968), Hollander (1979), Sowell (1994)—recognizing Keynes's misrepresentation of Mill, and taking the view that "it is all there" in Mill, have concluded it was quite wrong of Keynes to attribute to him belief in an untenable "classical" theory. Could it then be true-given his rejection of "Say's Identity"-that Mill's "macroeconomic theory" (if we may call it such) was actually of a character of which Keynes-had he studied it properly-would have approved? That is the question. To find the answer we must investigate Mill's handling of the key questions relating to spending and saving, investment and employment.

It is necessary to be aware of Mill's usage with respect to investment: he follows classical convention by explicitly including working capital-in particular, the subsistence of the workforce-in the category of investment or producers' goods. Investment is in fact quite typically envisaged as involving simply the purchase of wage goods to maintain labor, rather than the acquisition of durable capital goods. 
In his 1844 Essays Mill categorically asserted that production in itself guarantees a corresponding demand for goods. Again, in the Principles, we find that proposition emphatically stated:

\begin{abstract}
[W] hoever brings additional commodities to the market, brings an additional power of purchase ... also an additional desire to consume; since if he had not that desire, he would not have troubled himself to produce. Neither of the elements of demand [neither "ability" nor "desire" to purchase] therefore can be wanting, when there is additional supply; though it is perfectly possible that demand may be for one thing and the supply may unfortunately consist of another. (Mill 1866, bk. III, ch. xiv, p. 3)
\end{abstract}

The proposition is clear: the motive to produce implies a simultaneous desire to acquire goods. There may be, on this argument, misalignment of supply and demand at the micro level, but there can be no overall excess of supply over demand-both the necessary ability and will to buy exist. Could saving cause a problem? Mill's answer (1866, bk. III, ch. iv, p. 3) is that a readiness to save would not "in the smallest degree affect our conclusion." All savings, he contends, will-under normal conditions-be productively employed; income that is saved by the better-off within the community will automatically pass into the hands of the laboring class. And, if workers offer themselves for work, they must have unsatisfied needs - they can therefore be expected to spend the wages they receive. Spending by workers can therefore be relied upon to offset the savings of the propertied classes. Demand will match supply.

In the Principles (bk. III, ch. xiv, "Of Excess of Supply") Mill meets the "general glut" protagonists head-on. He states his intention of dealing with the question of a possible deficiency of aggregate demand by examining separately "the two elements of demand"- "the desire to possess" and "the means of purchase." This is of course where, so to say, we came in: Mill's famously misquoted passage is introduced to establish that the ability to purchase cannot fall short of the value of output produced. The ability to buy thus dealt with, Mill turns to the crucial matter of the desire to buy. He explains why — as he sees the situation - the spending of the workers will offset the savings of the wealthy.

Mill seeks to demonstrate that, no matter how large a proportion of their income the wealthy save, demand and employment will not be affected.

\begin{abstract}
For what do these persons do with their savings? They invest them productively; that is, expend them in employing labour. In other words, having purchasing power belonging to them, more than they know what to do with, they make over the surplus of it for the general benefit of the labouring class. Now, will that class also not know what to do with it? . . until the working classes have also reached the point of satiety . . . there will be no want of demand for the produce of capital, however rapidly it may accumulate ... in whatever manner the question is looked at, even though we go to the extreme verge of possibility to invent a supposition favourable to it, the theory of overproduction implies an absurdity. (Mill 1866, bk. III, ch. xiv, p. 3)
\end{abstract}

In contending that by saving the propertied classes "make over" their surplus purchasing power to laborers, Mill was returning to the argument he had developed earlier in his treatise (Mill 1866, bk. I, ch. v, p. 3) against the "common doctrine" (associated with Malthus, Chalmers, and Sismondi) that "the unproductive expenditure of the rich is necessary to the employment of the poor." As reassurance to the sceptical Mill proposes 
an "extreme case" to demonstrate that, however much the well-to-do save out of their incomes, an increase in savings will not adversely affect employment through a shortfall of aggregate demand. What, he asks, will happen if the propertied classes, say from "conscientious motives," determine to reduce their consumption to no more than that of a "well-conducted labourer"? "How is the increased capital to find employment? Who is to buy the goods it will produce? There are no longer customers even for those which were produced before. The goods, therefore (it is said) will perish in the warehouse" (Mill 1866, bk. I, ch. iv, p. 3).

Then comes Mill's characteristic argument:

\begin{abstract}
But this is seeing only one-half of the matter. In the case supposed, there would no longer be any demand for luxuries, on the part of capitalists and landowners. But when these classes turn their income into capital, they do not thereby annihilate their power of consumption; they do but transfer it from themselves to the labourers to whom they give employment. [As regards the number of laborers, there are two possibilities]: either there is, or is not, an increase of their number proportional to the increase of capital. If there is ... the production of necessaries for the new population, takes the place of the production of luxuries for a portion of the old, and supplies exactly the same amount of employment which has been lost.
\end{abstract}

On the alternative supposition that there is no increase of population, Mill's prediction is that luxuries are produced as before but now "shared among the community generally." All output produced is bought by someone. Thus he draws the conclusion: "[T]he limit of wealth is never deficiency of consumers, but of producers and productive power. Every additional capital gives to labour either additional employment, or additional remuneration" (ibid.).

Mill's assurance to his readers is that saving or, specifically, increased saving out of current income, poses no threat, whether or not the workforce increases, to the reliable absorption by intended demand of all output offered for sale (a commercial crisis, of course, aside). The argument-advanced with great confidence-is that all income saved by the propertied classes will-must — find its way into the hands of the laboring class, who will undoubtedly spend what they get; i.e., saving, just as much as consumption, necessarily implies spending.

\title{
V. WHOSE DEMAND COUNTS?
}

Let us use a simple model to examine Mill's thesis. Imagine a two-sector surplusproducing economy. The wage-goods sector employs seventy units of labor to produce (per annum) $£ 100$ worth of wage-goods; the luxury goods sector employs thirty units of labor and produces $£ 40$ worth of luxury goods. The wage rate is $£ 1$ per unit of labor per annum. The workers spend all their incomes on wage-goods, and the capitalists, who employ the workers, spend all their profits on luxuries. The annual wage bill totals $£ 100$ ( $£ 70$ paid in wage-goods production and $£ 30$ in production of luxuries), all of which goes to purchase wage-goods. Total profits are $£ 40$ ( $£ 30$ in the wage-goods sector and $£ 10$ in luxury goods) and, in the situation initially assumed, those profits are wholly expended on the acquisition of luxury goods. (For simplicity we exclude the possibility that the capitalists consume a share of basic wage-goods.) 
Suppose there now occurs Mill's postulated outbreak of thrift, with the capitalists refraining from luxury consumption. What happens then? The capitalists, we are told, 'invest their savings productively'; they "expend them in the employment of productive labour." (We suppose that wage-goods represent all the producers' goods required to support labor in employment.) Thus the capitalists' demand is switched from luxuries to wage-goods to be used "to put labour into motion." Following this change in the pattern of demand, total employment remains at 100, but wage-goods production replaces luxury production. With all labor now engaged in the wage goods-sector, the output of wage-goods is increased (say, proportionately) from $£ 100$ to $£ 143$ worth of wage-goods. There are then, according to Mill, two possibilities: the labor force increases pari passu with the increase in the supply of wage-goods, or it remains as before.

Before considering these alternative scenarios regarding the size of the labor force, we ask: Why should it be supposed that labor released from luxury production will automatically be redeployed to the production of wage-goods? Demand for luxuries has suddenly slumped - because of a change in social values. Why should capitalists in these circumstances wish to expand production capacity by so increasing the stock of resources as to be able to put $43 \%$ extra labor "into motion"? If workers are transferred from producing luxuries to producing extra wage-goods, the current supply of wage-goods will, it is true, be consumed by the same existing labor force (100), but the question is: Why should this production of extra wage goods be profitable? As Malthus (1836, pp. 314 $315)^{10}$ had emphasized, the demand of the workforce for the wage goods they themselves are currently producing cannot be sufficient to yield a profit to the capitalist employer. The anticipated profitability of transferring workers from luxury to wage-goods production depends on the capitalists' expectations of the existence of a market for the extra output of wage-goods (£43), which increased employment (from 70 to 100) in the wagegoods sector would produce in the future. The capitalists must foresee a market for the output that the larger workforce will produce. What, then, is the incentive for the employers to undertake an increase in production such as to justify the increase in employment now made possible? Mill has nothing (directly) to say on that. ${ }^{11}$

But even if that increased output of wage-goods were to be taken up by a proportionate increase in total employment (from 100 to 143), the issue remains: the means to support a further increase in the number employed (this time from 143 to 204) will be created-but will these resources be put to use? Again, it is not their own demand for wage-goods that ensures employment of workers, but the employers' expectation that there will be sufficient future demand to yield a profit on the further output these 204 extra units of labor will produce.

The point is that way in which Mill tells the story is misleading: workers may consume the additional supply of wage-goods, but, if they do, it is not-as Mill would seem to imply - these workers' own natural willingness to buy that is the critical factor

\footnotetext{
${ }^{10}$ Malthus (1836, p. 315): "the consumption and demand occasioned by the workmen employed in productive labour can never alone furnish a motive to the accumulation and employment of capital."

${ }^{11}$ Hollander (1985, pp. 374-375) notes that Mill's discussion of these matters is less than satisfactory. Thus, on Mill's observation (1866, bk. I, ch. v, p. 3) that "the production of necessaries for the new population takes the place of the production of luxuries for a portion of the old," Hollander comments: "This may be true, but it does not in itself explain the source of the purchasing power for the net flow of output from the expanded national capacity once in place." Exactly!
} 
in ensuring that the extra supply of wage-goods does not go to waste. Existing or additional employees will be able to buy wage-goods only if the capitalists think it worthwhile to invest in their employment. The determining factor is always the capitalists' expectations that surplus value can be raised from the sale of the (extra) output that (extra) workers will produce. Mill makes much of the workers' readiness to spend, but that is beside the point. As regards the generation of demand, the workers cannot be regarded as independent agents whose needs create an alternative source of demand that automatically compensates for a cut in consumption by the propertied classes.

The alternative possibility envisaged by Mill is that, following the postulated outbreak of thrift among the wealthy, no increase takes place in the number of available workers and the surplus luxury goods are distributed to the existing workforce. Presumably the supposition is that the capitalists attempt to take on more labor, and, the supply of labor being completely inelastic, real wages are bid up, bringing the workers to a luxury goods-consuming level of income. At any rate, Mill is again arguing that the workers will consume what the thrifty capitalists have left aside. Consider what this means in terms of our example. The output of luxury goods previously purchased out of profits is now acquired by the workforce. In other words the workers have command not only of the current output of wage-goods, but of everything else produced-the wage bill paid by the employers constitutes purchasing power over all national output. The rate of profit is reduced to zero with the disappearance of the capitalists' share of output. That does not seem conducive to equilibrium at full employment in a capitalist economy.

Let us pause to take stock. Mill is asserting that increased savings do not mean less spending: rather, different people do the spending (workers on wage-goods instead of capitalists on luxuries). But if extra workers are to spend on extra wage-goods, the capitalists must expect it will be profitable to employ these additional workers. Mill ignores Malthus's point that demand other than that of the workers employed in producing the extra wagegoods is necessary to make profitable that production. The issue of demand in fact receives no explicit attention. Mill focuses on output (of wage-goods). He holds—see his paradoxical "fourth proposition on capital" - that an increased output of the means of putting labor into motion is sufficient to ensure (not merely permit) an increased volume of employment. It would seem that, in accounting for the level of employment, Mill is more concerned with the availability of resources to support labor in employment than with the sufficiency of demand to take up the output produced through that employment.

\section{VI. "DEMAND FOR COMMODITIES IS NOT DEMAND FOR LABOUR"}

That Mill does not view the state of demand for output as the critical factor in determining employers' demand for labor is evident from his "fundamental propositions on capital" (Mill 1866, bk. I, ch. v). ${ }^{12}$ Mill's "fourth fundamental proposition on capital"

\footnotetext{
${ }^{12}$ Kates (2015) presents — he is sympathetic to Mill—a careful assessment of Mill's "four fundamental propositions concerning capital." Kates finds no problem with these propositions. We, on the contrary, are particularly uncomfortable with the fourth proposition: it fails to recognize explicitly that not only is capital necessary to "put labour into motion," but that there must be present also-if that capital is actually to be invested - a factor that cannot be guaranteed always to exist; i.e., an appropriate expectation of the profitability of investment (along with a sufficient degree of confidence) on the part of investors.
} 
(1866, bk. I, ch. v, p. 9) - a corollary of his (unexceptional) first proposition (that "industry is limited by capital")—-states:

\begin{abstract}
What supports and employs productive labour, is the capital expended in setting it to work, and not the demand of purchasers for the produce of the labour when completed. Demand for commodities is not demand for labour. The demand for commodities determines in what particular branch of production the labour and capital shall be employed: it determines the direction of the labour; but not the more or less of the labour itself, or of the maintenance or payment of the labour. (emphasis added)
\end{abstract}

Of the above "theorem" Mill—revealing the importance he attaches to it—observes:

This is a proposition which greatly needs all the illustration it can receive. It is, to common apprehension, a paradox; and even among political economists of reputation, I can hardly point to any, except Mr. Ricardo and M. Say, who have kept it constantly and steadily in view.

It is clear that Mill believes any attempt to boost employment by encouraging the wealthy to save less and spend more, even if unemployment exists, to be quite pointless - such a strategy cannot create more jobs for the workers. It would in fact, by transferring labor from productive (wage-goods) to unproductive (luxuries) employment, ultimately reduce the capacity of the economy to provide employment. For higher employment, more saving, not more luxury consumption, is required. From this perspective the notion of there ever being "too much" saving makes no sense. ${ }^{13}$

\title{
VII. TO INCREASE EMPLOYMENT, MORE SAVING, NOT MORE SPENDING, IS NEEDED
}

Why does Mill insist that increased saving rather than increased spending is necessary to ensure increased employment? He argues that without previous production of wagegoods it would be impossible to support additional workers in employment; saving to finance production of an increased supply of wage-goods must therefore come first, otherwise more workers cannot be "put into motion." The situation envisaged by Mill is that if (as recommended by Malthus) the wealthy are persuaded to increase their demand for luxury goods, workers will be transferred from production of wage-goods to production of luxuries. Initially, there is no change in total employment, but subsequently, with wage-goods production capacity reduced, it becomes impossible to provide support for as many_let alone additional—workers as before. According to Mill, the Malthus policy will harm, not help, the laboring class.

While Mill's understanding that wage-goods must be available if labor is to be "put into motion" is of course correct, he apparently fails to recognize that, under depression

\footnotetext{
${ }^{13}$ Note Mill (1866, bk. I, ch. v, p. 3): "While on the one hand industry is limited by capital, so on the other, every increase of capital gives, or is capable of giving, additional employment to industry; and this without assignable limit. ... [the portion of the increased capital] which is destined [to the maintenance of labor] may (supposing no alteration in anything else) be indefinitely increased, without creating an impossibility of finding them employment: in other words, . . . if there are human beings capable of work, and food to feed them, they may always be employed in producing something."
} 
conditions with idle production capacity, it is certainly possible that a higher demand for labor (stimulated by increased demand for either luxuries or capital goods) can directly increase employment. Unemployed workers-even if in straitened circumstances-are (somehow) receiving subsistence and are available for employment; as employment rises, an increased supply of wage-goods may be expected to come to the market. If landowners borrow in order to add to their luxury expenditures, or capitalists draw on idle balances to finance investment, rather than the existing output of wagegoods being diverted from one use to another, extra wage-goods for supporting extra employment may quickly be supplied by increased production (or from existing stocks). With idle men and equipment the means of supporting extra workers in employment are readily obtainable without curtailing the existing supply of wage-goods. But an increased supply of the means of "putting labour into motion" will not, per se, bring about increased employment: employers must anticipate that it will be profitable to offer that extra employment. That is vital—availability of the means of supporting additional labor in employment is a necessary, not a sufficient, condition for employment to increase.

Mill, however, is absolutely definite that, even if unemployment exists, extra spending by the wealthy on luxuries simply cannot boost demand for labor. As a reductio ad absurdam intended to give the coup de grâce to the Malthusian focus on demand, Mill cites the operation of the Poor Law, asking how his own spending on luxuries could possibly be of benefit to the poor.

If it be equally for the benefit of the labouring classes [Malthus's contention] whether I consume my means in the form of things purchased for my own use or set aside a portion in the shape of wages or [by paying the Poor Rate] alms for their direct consumption, on what ground can the policy be justified of taking my money from me to support paupers?

... [C]ommon sense tells us [however] ... that if [I] had not been required to pay the rate, and had consequently laid out that amount on [myself], the poor would have had as much less for their share of the total produce of the country, as [I] myself had more. (Mill 1866, bk. I, ch. v, p. 9)

Mill's conclusion: it is saving, not consumption spending by the well-to-do, that benefits the laboring class. It is of course true that under the Poor Law resources are transferred (forced saving) from the control of the well-off directly into the hands of paupers, who will certainly spend what they receive. So far, so good: "I" consume less, the paupers consume more. But is the case of the workers analogous? Is it, as Mill argues, "my" saving, voluntary or forced, not "my" consumption, that benefits the workers?

Does this "parable" validate Mill's contention that no amount of saving by the propertied classes can be detrimental to the workforce? It does not: Mill is apparently confusing a strategy that would be appropriate to promote capital accumulation and growth of employment with what is necessary to increase the utilization of resources already available. His argument fails on two grounds. First, increased luxury consumption can be beneficial to labor. If, when additional luxury spending or investment is undertaken, underutilized capacity exists, the size of Mill's "cake" can be increased via greater production of wage-goods (Malthus's argument). More wage-goods can be made available to support more workers in employment. Second, savings will not turn into spending and employment unless by the decisions of the employers. Employers are 
not engaged in the distribution of charity: unless the employment of more workers will profit the capitalists, extra wage-goods will indeed "perish in the warehouse."

\section{SAVING, INVESTMENT, AND PROFIT}

In explaining as he does what determines employment, Mill's focus is on supply-side conditions - on the ability of the economy to support labor in employment, rather than (commercial crises aside) on the adequacy of demand for output such as to justify full employment of the available labor force. In arguing, as we have seen, that there cannot be "too much" saving out of income, he appears to neglect the demand side completely, taking it for granted that if means to support labor are provided, the employment of that labor is guaranteed. No matter how drastically the propertied classes cut back on luxury spending, the resources thereby released will, he insists, automatically be applied to the support of productive labor.

To Mill, what matters for employment is the availability of resources to "put labour into motion." Why, we must ask, is Mill always so sure that that if, through saving, more wage-goods are made available for the support of labor in employment, employers will actually be prepared to invest and take on a corresponding number of extra employees?

Although the incentive for capitalists to invest receives no explicit consideration in Mill's argument that workers' spending necessarily offsets saving by the well-to-do, it is difficult to believe that he could have taken workers' readiness to spend as the sole factor in maintaining demand and employment. It is clear that Mill sees investment as the means of transferring purchasing power from savers to workers. And as regards investment, he devotes a whole chapter of the Principles (bk. II, vol. xv) to explaining that the prospect of profit is the necessary inducement for capitalists to postpone consumption, put in personal effort, and to risk resources on investment. It therefore seems improbable that in the context of his maximum savings and Poor Law examples Mill simply overlooked the investment incentive: more likely he had some explanation of investors' behavior in mind. What we are about to suggest is that he took it for granted that properly directed investment in the employment of labor must always (crisis conditions aside) be profitable to the capitalist, implying that there is no reason to fear that savings may not always be accompanied by an equal volume of intended investment. For Mill, as regards the volume of employment, the critical issue is the availability of resources with which to support labor in employment, not whether there exists demand for the output of that labor. He foresees no problem with respect to the latter.

On what grounds is Mill's confidence based that planned investment can be depended upon to match savings? Does he rely on changes in the rate of interest to bring savings and intended investment into equality? While he does speak elsewhere of the rate of interest as determined by demand and supply of loanable funds, in the context of his maximum savings example, there is no hint at all of interest playing an equilibrating role.

Mill apparently holds that (at least so long as the direction of investment is appropriate and resources are available at acceptable cost) the capitalist can be sure of profit 
on his outlay. Why so? The generation of profit, Mill believes, is the natural and characteristic outcome of investment in the employment of productive labor. He explains what he understands to be the true source of profits:

It thus appears that the two elements on which, and which alone, the gains of the capitalists depend, are, first, the magnitude of the produce, in other words the productive power of labour; and secondly, the proportion of the produce obtained by the labourers themselves. . . . These, therefore, are . . the circumstances which determine the rate of profit: and it cannot be in any way affected except through one or other of them. ... And there is no other combination of circumstances, in which the general rate of profit of a country, in all employments indifferently, can either rise or fall. (Mill 1866, bk. II, vol. iv, p. 7)

For Mill the source of profit lies in the ability of productive labor to produce a surplus of output over the renewal of all means of production, including the maintenance of the labor employed. He insists - no qualification allowed - that the only factors on which the profit of the capitalist depends are the productivity of labor and the share of the surplus over all other costs of production that falls to labor.

As Mill fully appreciates (1866, bk. II, vol. xiv, p. 7), he is simply reiterating David Ricardo's theory of profit. What is significant in the present context is that Mill apparently accepts, without any reservation, all that Ricardo's analysis might be taken to imply. As to the implications, Ricardo himself states:

There cannot then be accumulated in a country any amount of capital which cannot be employed productively, until wages rise so high in consequence of the rise of necessaries, and so little consequently remains for the profits of stock, that the motive for accumulation ceases. (Ricardo [1821] 1966, p. 193)

Joseph Schumpeter and Samuel Hollander each spell out the full implications of the unqualified Ricardian theory. Thus Schumpeter (1954, p. 261n8): “except for a rise in the real value of wages, investment is possible to an infinite extent without depressing the rate of profits." Likewise Hollander (1979, p. 522): "The Ricardian position [is] that in the absence of the operation of diminishing returns, or any other force causing 'real' wages to vary, the demand for investment funds based upon capital productivity will be infinitely elastic...." That, we believe, is exactly how Mill interpreted Ricardo's theory that, given appropriate conditions in respect of productivity and real wages, the profitability of new investment can be taken for granted. The trouble is that Ricardo's neglect of the implications of uncertainty of the investment's outcome makes unreserved adoption of his theory of profits a completely inappropriate basis for an attack on the "heretics." The fact that under given circumstances the productivity of labor may make possible a physical surplus of output over all costs does not mean that at the same time market conditions - the state of demand for output and expected pricesare necessarily such that the investor can look forward to a corresponding return in terms of surplus value.

Mill does not seem to appreciate that a prospective value surplus, not just a potential surplus of physical output, is essential for production and investment to be undertaken. He insists - quite wrongly, we believe-(1866, bk. II, vol. xv, p. 6) that "profit arises, not from the incident of exchange, but from the productive power of labour, and the general profit of the country will always be what the productive power of labour makes it, 
whether any exchange takes place or not" (emphasis added). But what if, say, a brick maker, producing more than enough bricks to make a profit if these bricks are sold, finds stocks of unsold bricks accumulating because investors elsewhere in the economy are for some reason reluctant to risk their capital? It certainly does matter to the brick maker whether "exchange takes place or not." Neither does it follow, as Mill claims (1866, bk. II, vol. xv, p. 6), from the fact of the physical productivity of the economic system that, "if the labourers of a country collectively produce twenty per cent more than their wages, profits will be twenty per cent, whatever prices may or may not be." But for the transformation of a physical surplus into a value surplus-which of course is what the capitalist is seeking-exchange and prices do matter. Mill (1866, bk. II, vol. xv, p. 6) certainly appears to be laboring under a misapprehension when he dismisses as superficial misunderstanding the "popular" view that "it is by the sale of their goods that [capitalists] replace their capital and add to its amount."

Although Mill understands how in a financial panic there develops a desperate desire for the security that derives from holding money, that insight is not carried over to his discussion of investment behavior under more normal circumstances. But it is not only in a commercial crisis that investment is subject to risk and uncertainty. Mill does not admit the possibility that, under non-crisis conditions, available resources may be withheld from investment because prospective profits are deemed insufficient to make up for the risks and uncertainties involved.

\section{MILL'S PERSPECTIVE}

We think it highly significant that in concluding his case against the "heretics" Mill acknowledges (1866, bk. III, vol. xiv, p. 4), in fulsome terms, his predecessors and mentors:

It is but justice to two eminent names, to call attention to the fact that the merit of having placed this most important point in its true light belongs principally, on the Continent, to the judicious J. B. Say, and in this country to Mr Mill; who . . . has set forth the correct doctrine with great force and clearness in an early pamphlet ... entitled "Commerce Defended."

What then was the "true light" (as Mill believed it to be) shed by James Mill and J. B. Say on the possibility of overproduction in relation to total demand? We cannot here review in detail their theories, but Steven Kates conveniently summarizes (2003, pp. 2-3 and 7; also Kates 2015) the essence of the orthodox doctrine as understood in the early nineteenth century. Thus: "Demand is constituted by supply. Aggregate demand is not independent of aggregate production but is identical with it." The implication of course being: "There [is] clearly no need to fear that insufficient demand will lay an economy low. This was the core conclusion of the law of markets, that whatever else might befall an economy, too little demand relative to production would never occur."

Such was the climate of opinion in which J. S. Mill intellectually grew up, and such were the views to which, we believe, he essentially remained wedded. We suggest that the root of the Mill problem (as seen from a Keynesian angle) lies in Mill's fundamental mind-set-a conceptual framework, an unquestioned belief, inherited from his father and Say, that the very act of supply to the market implies a corresponding 
"desire to possess." That conception of economic activity can be represented by the formula $C-M-C$ : commodities are produced and sold for money, and the money is used to buy other commodities. The purpose of economic activity is, that is to say, to acquire commodities for consumption: the producer either consumes his own product or exchanges it for the products of others. Money is merely an intermediary that facilitates exchange - the cycle of trade begins and ends with commodities. Sales receipts are always (the temporary disruption of a crisis aside) respent. No transactor intends to pull out of the market in the middle of the exchange process with money in hand instead of goods. In that situation "the means of purchase" and "the desire to possess" are both automatically present.

That schema may adequately represent what happens in a pre-capitalist economy with, say, farmers taking produce to weekly markets and exchanging their surplus corn or cabbages for clothes or tools brought to market by local craftspeople, but it does not describe what underlies commercial activity in a capitalist economy. The object of the capitalist is to turn money into more money-to realize surplus value by employing capital in productive activity. The appropriate representation is therefore not $C-M-C$ but $M-C-M^{\prime}$ : money is used to buy goods (including labor services), which are transformed via production into goods to be sold at a profit (with the rate calculated in terms of money). The purpose of the operation is to capture surplus value, not to end up with a stock of particular goods.

A modern commentator-John F. Henry (2003, p. 193) - focuses on this fundamental feature of capitalist reality, making the point that the economic world as envisaged by Say and the Mills is "not the economy that exists." He cites Keynes (and Karl Marx) as both having made exactly that point. Thus in an early draft of what would become the General Theory, Keynes (1979, pp. 66-82) wrote:

Marx had pointed out that the nature of production in the actual world is not, as economists seem often to suppose, a case of $C-M-C$, i.e. of exchanging commodity . . . for money in order to obtain another commodity.. . . That may be the standpoint of the private consumer. But it is not the attitude of business, which is a case of $M-C-M^{\prime}$, i.e. of parting with money for commodity . . in order to obtain more money. . . . An entrepreneur is interested, not in the amount of product, but in the amount of money which will fall to his share. ${ }^{14}$

Even before Marx, Thomas Chalmers (1832, pp. 64-66), in a passage that Mill must have read, clearly identified the prime object of the capitalist entrepreneur: in his investment of money, the objective of the capitalist man of business is not to acquire commodities, but to make more money:

If [a merchant] starts at present with a certain sum expressed in pounds, shillings and pence, the great end of his exertion or enterprise is, that after the current speculation is completed, he might start anew on another speculation, with a larger sum, expressed as before in pounds, shillings and pence. (emphasis added)

\footnotetext{
${ }^{14}$ Thus Marx ([1867] 1976, p. 50): "The path $C-M-C$ proceeds from the extreme constituted by one commodity, and ends with the extreme constituted by another, which falls out of circulation and into consumption. Consumption, the satisfaction of needs, in short use-value, is therefore its final goal. The path $M-C-M$, however, proceeds from the extreme of money and finally returns to that same extreme. Its driving and motivating force, its determining purpose, is therefore exchange value."
} 
With impressive perception, Chalmers concludes: "Had this consideration been kept in view, we feel persuaded that the doctrine of the impossibility of a universal glut would never have been framed." Chalmers's observation goes straight to the heart of the matter. He realized that the proponents of the orthodox doctrine had failed to understand the nature of commercial operations in a capitalist economy, and the motivation that powers the system.

That Mill was not thinking of the capitalist entrepreneur's immediate motive as being the accumulation of money-rather than consumer goods-is evident from his observation (1866, bk. I, vol. v, p. 9) that, should demand for a particular product (velvet) a capitalist is offering to the market be wanting,

[v]elvet will not be made; but ... manufacturers and their labourers do not produce for the pleasure of their customers, but for the supply of their own wants, and [having resources available] they can either produce something else which is in demand, or if there is no other demand, they themselves have one, and can produce the things they want for their own consumption. ${ }^{15}$

It is, we suggest, from Mill's adherence to the goods for goods $(C-M-C)$ conception of economic activity that the fundamental difference between his and the Keynesian vision stems. Mill's analysis of aggregate demand and employment is inappropriately tied to the conditions of a pre-capitalist, pre-industrial world, in which supply of goods does indeed imply demand for goods. On the other hand, the M-C-M' conception of Marx and Keynes recognizes the characteristic feature of the capitalist economy: with M-C-M' the supply of goods represents demand for surplus value, not for goods directly, and that, when there is fear that surplus value will not be realized, the circuit will not then be restarted: savings will not be directed to investment.

\section{CONCLUSION}

The object of this paper has been to demonstrate the falsity of the perhaps surprising, but apparently not uncommon, view-based, it would seem, on awareness of J. S. Mill's rejection of Say's Identity—-that, in modern (Keynesian) terms, Mill's “macro" analysis is essentially acceptable. In fact what Mill presented in the Principles was a curious hybrid. On recognizing that a demand for money per se could emerge on the occasion of a financial crisis, he concluded that the proposition now known as "Say's Identity" was untenable. He nevertheless clung to the "supply constitutes demand" thesis as the basic explanation of how expenditure is determined.

What Mill put forward was a version of the Say-James Mill proposition that to supply goods to the market implied a corresponding demand to take other goods from the market. Mill qualified the basic proposition by allowing that in certain extreme conditions it would not apply. In these situations the expression of intended demand as actual demand could be frustrated not by a lack of desire to acquire goods, but by fear of the dangers of engaging in commercial operations at a time of extreme uncertainty

\footnotetext{
${ }^{15}$ To which Mill adds, confirming his belief that employment depends on the demand for labor (as represented by the availability of the means of putting labor into motion), not demand for the product: "So that the employment afforded to labour does not depend on the purchasers, but on the capital."
} 
and risk of financial loss. Mill was in effect attempting a reconciliation of the "law of markets" à la Say and James Mill with the evident fact of observation that at times the community did indeed prefer money to goods.

The implications of Mill's analysis are (1) that general demand-deficient unemployment can occur only (briefly) on the occasion of a liquidity crisis/credit crunch-under other circumstances supply certainly does create corresponding effective demand; (2) that full recovery from a commercial crisis is automatic and rapid; and (3) that while Mill's theory might comprehend dramatic oscillation of the economy between boom and slump, there is no way in which his analysis can account for prolonged periods of low activity and high unemployment. To repeat: Mill's understanding was that, in normal circumstances, the volume of employment was determined by the quantity of resources available to "put labour into motion," not by vagaries of planned expenditure.

There can be no question that Mill's conception of the working of the macroeconomic system was fundamentally at odds with that of Keynes. Mill may not have held by "Say's Identity" but he certainly believed - the transient (and supposedly) self-correcting circumstances of a financial crisis aside - that supply did indeed create its own demand. To believe otherwise constituted an irrational heresy.

\section{REFERENCES}

Baumol, William J. 1999. "Retrospectives: Say's Law.” Journal of Economic Perspectives 13: 194-204.

Becker, Gary A., and William Baumol. 1952. "The Classical Monetary Theory: The Outcome of the Discussion." Economica 19: 355-376.

Chalmers, Thomas. 1832. On Political Economy in Connexion with the Moral State and Moral Prospects of Society. Glasgow: William Collins.

Davis, J. Ronnie. and Frank J. Casey, Jr. 1977. “Keynes’s Misquotation of Mill.” Economic Journal 87: 29-30. Henry, John F. 2003. "Say's Economy.” In Steven Kates, ed., Two Hundred Years of Say's Law. Cheltenham: Edward Elgar, pp. 187-198.

Hollander, Samuel. 1979. The Economics of David Ricardo. London: Heinemann. . 1985. The Economics of John Stuart Mill. Oxford: Basil Blackwell.

Kates, Steven. 1998. Say's Law and the Keynesian Revolution: How Macroeconomic Theory Lost Its Way. Cheltenham: Edward Elgar.

Kates, Steven, ed. 2003. Two Hundred Years of Say's Law. Cheltenham: Edward Elgar.

Kates, Steven. 2015. "Mill's Fourth Fundamental Proposition on Capital: A Paradox Explained." Journal of the History of Economic Thought 37: 39-56.

Keynes, John Maynard. 1936. The General Theory of Employment, Interest and Money. London: Macmillan. . 1973. Collected Writings. Volume XIII, The General Theory and After, Part 1, "Preparation." Edited by Donald Moggridge. London and Basingstoke: Macmillan for the Royal Economic Society.

- 1979. Collected Writings. Volume XXIX, The General Theory and After: A Supplement. Edited by Donald Moggridge. London and Basingstoke: Macmillan for the Royal Economic Society.

Knight, Frank H. 1937. "Unemployment and Mr. Keynes's Revolution in Economic Theory." Canadian Journal of Economics and Political Science: 100-123.

Leijonhufvud, Axel. 1966. On Keynesian Economics and the Economics of Keynes. New York: Oxford University Press.

Malthus, Thomas Robert. 1836. Principles of Political Economy. Second edition. London: William Pickering. Marshall, Alfred, and Mary Paley Marshall. 1879. The Economics of Industry. London: Macmillan.

Marx, Karl. [1867] 1976. Capital. Volume One. London: Penguin Books.

Mill, John Stuart. [1844] 1963-68. Essays on Some Unsettled Questions of Political Economy. In J. M. Robson, ed., Collected Works of John Stuart Mill. Toronto: University of Toronto Press. 
1866. Principles of Political Economy. London: Longmans, Green, Reader and Dyer.

Mummery, Albert F., and John A. Hobson. [1889] 1956. The Physiology of Industry. New York: Kelly and Millman.

Mundell, Robert A. 1968. Man and Economics. New York: McGraw-Hill.

Patinkin, Don. 1965. Money, Interest and Prices. Second edition. New York: Harper \& Row.

Ricardo, David. [1821] 1966. The Principles of Political Economy and Taxation. London: Dent.

Schumpeter, Joseph A. 1954. History of Economic Analysis. London: Allen \& Unwin.

Sowell, Thomas. 1994. Classical Economics Reconsidered. Princeton, NJ: Princeton University Press.

Whitaker, John K., ed. 1975. The Early Economic Writings of Alfred Marshall. London: Macmillan for the Royal Economic Society. 